\title{
Physiological characterization of natural transformation in Acinetobacter calcoaceticus
}

\author{
Ronald Palmen, Ben Vosman, $†$ Pieter Buijsman, Cornelis K. D. Breek \\ and KLAAS J. HellingWERF*
}

Department of Microbiology \& Biotechnology Centre, University of Amsterdam, Nwe. Achtergracht 127, 1018 WS Amsterdam, The Netherlands

(Received 5 June 1992; revised 2 September 1992; accepted 5 October 1992)

\begin{abstract}
Acinetobacter calcoaceticus BD413 develops competence for natural transformation immediately after the start of the exponential growth-phase and remains competent up to a few hours into the stationary phase, after which competence gradually declines. The transformation frequencies obtained strongly depend on the kind of transforming DNA and the incubation time with DNA. Up to $25 \%$ of the cells in a culture can be transformed. DNA uptake in Acinetobacter does not display sequence specificity, is $\mathrm{Mg}^{2+}$, $\mathrm{Mn}^{2+}$ - or $\mathrm{Ca}^{2+}$-dependent and is uncoupler sensitive. The transforming DNA enters the cells in single-stranded form. These properties constitute a unique combination, not previously observed in other bacteria, and make $\boldsymbol{A}$. calcoaceticus ideally suited for detailed studies of the bioenergetics of DNA translocation.
\end{abstract}

\section{Introduction}

Natural transformation is a feature that allows (prokaryotic) cells to take up naked DNA from the environment and exploit the coding capacity of the internalized nucleic acid. This transformation system is encoded by the genome of the recipient, and competence for natural transformation is induced under physiological conditions without the use of chemical or (bio)physical treatment of the cells as in artificial transformation. An understanding of this process is of importance for such widely diverse topics as safety of the release of genetically engineered organisms and estimation of the importance of sexual interactions between bacteria for prokaryotic evolution.

Natural transformation is observed in a wide range of organisms. Among these are representatives of both Gram-positive (e.g. Bacillus subtilis, Dubnau, 1991; Streptococcus pneumoniae, Avery et al., 1944), and Gram-negative bacteria (e.g. Haemophilus influenzae, Neisseria gonorrhoeae, Azotobacter vinelandii, Pseudo-

* Author for correspondence. Tel. 20 5255002; fax 205255698.

$\dagger$ Present address: Centre for Plant Breeding and Reproduction Research (CPRO-DLO), Droevendaalsesteeg 1, Postbus 16, 6700 AA Wageningen, The Netherlands.

Abbreviation: IVL, isoleucine, valine, leucine monas stutzeri; for a review see Stewart \& Carlson, 1986). As more and more details of natural transformation in a number of these bacteria have been elucidated, it is becoming clear that distinct differences exist in this process between these organisms. Wellknown examples are the sequence specificity of DNA uptake in Haemophilus (Goodgal, 1982) and Neisseria (Goodman \& Scocca, 1991), which is not seen in some of the other bacteria, and the very pronounced and complex regulation of competence development in Bacillus subtilis (Dubnau, 1991). These differences suggest that not only the mechanism of DNA uptake in natural transformation differs among these bacteria, but that possibly its function varies also in different species.

Acinetobacter calcoaceticus, a Gram-negative, naturally transformable and metabolically versatile organism, has been the subject of much study over the last 30 years. These studies predominantly concerned the physiology of the organism, most often inspired by its very broad degradative capacity (Juni, 1978).

Our interest in A. calcoaceticus is to use it as a model to study natural transformation in Gram-negative bacteria, because high transformation frequencies can be obtained and it is easily grown in a competent state (Juni \& Janik, 1969; Juni, 1972; Sawula \& Crawford, 1972; Ahlquist et al., 1980). This is important because many basic questions remain unsolved. Three important questions follow. (i) What mechanism allows passage of a large nucleic acid molecule through the cell envelope of 
a (Gram-negative) bacterial cell? (ii) How is the investment of free energy coupled to this translocation process? (iii) What is the biological function of natural transformation in a particular organism? We think that, to tackle these questions successfully, a genetic approach must be used. Elsewhere, we describe the identification and characterization of the first set of mutants of $A$. calcoaceticus, which have an altered capacity to undergo natural transformation (Palmen et al., 1992).

In this study, we present data on the physiological characterization of natural transformation in $A$. calcoaceticus. Using transformation frequencies, the optimal conditions for transformation have been determined. Additionally, we achieved a qualitative description of DNA uptake during natural transformation of $A$. calcoaceticus.

\section{Methods}

Bacteria, media and chemicals. The strains and plasmids used in this study are listed in Table 1. Restriction enzymes were used as recommended by the manufacturer (Pharmacia LKB). Luria-Bertani medium (LB) and LB-agar were prepared as described previously (Vosman \& Hellingwerf, 1991). Minimal medium and minimal agar were prepared according to Juni (1974). They contained $60 \mathrm{~mm}$-lactic acid, $11 \mathrm{~mm}-\mathrm{KH}_{2} \mathrm{PO}_{4}, 95 \mathrm{~mm}-\mathrm{Na}_{2} \mathrm{HPO}_{4}, 0.81 \mathrm{~mm}-\mathrm{MgSO}_{4}, 37 \mathrm{~mm}-$ $\mathrm{NH}_{4} \mathrm{Cl}, 0.068 \mathrm{~mm}-\mathrm{CaCl}_{2}$ and $1.8 \mu \mathrm{M}-\mathrm{FeSO}_{4}$.

DNA isolation. Chromosomal DNA was isolated as described by Vosman \& Hellingwerf (1991). Plasmid DNA was isolated according to the method of Ish-Horowicz \& Burke (1981). Single-stranded DNA was obtained by heating double-stranded DNA at $95^{\circ} \mathrm{C}$ for $10 \mathrm{~min}$ and subsequent rapid chilling on ice. Additional molecular genetic techniques were applied according to Maniatis et al. (1982).

Transformation. A. calcoaceticus was grown to competence as follows. An overnight culture in LB or minimal medium $(1 \mathrm{ml})$ was diluted into $25 \mathrm{ml}$ of fresh medium and cultured for an additional $2 \mathrm{~h}$ at $30^{\circ} \mathrm{C}$. At this stage the culture is competent for genetic transformation. For transformation, $0.5 \mathrm{ml}$ of culture was incubated with approximately $2 \mu \mathrm{g}$ DNA (unless stated otherwise) for $60 \mathrm{~min}$ at $30^{\circ} \mathrm{C}$. After incubation, $50 \mu \mathrm{g}$ DNAase I (stock solution: $5 \mathrm{mg} \mathrm{ml}^{-1}$ ) was added to prevent further DNA uptake. When prototrophy for isoleucine, valine and leucine (IVL) auxotrophy was selected, the transformation mixture was directly plated on minimal-agar plates without IVL. In case of selection for antibiotic resistance, the transformation mixture was incubated for an additional hour to allow expression of the marker. Antibiotic-resistant transformants were selected on media containing $15 \mu \mathrm{g}$ kanamycin $\mathrm{ml}^{-1}, 100 \mu \mathrm{g}$ rifampicin $\mathrm{ml}^{-1}$ or $100 \mu \mathrm{g}$ ampicillin $\mathrm{ml}^{-1}$, depending on the resistance marker used. The viable count was determined on LB-plates. Colonies were counted after incubation for $2 \mathrm{~d}$ at $30^{\circ} \mathrm{C}$. The transformation frequency was calculated as the number of transformed cells, divided by the total viable count.

Effect of $p H$ on natural transformation. A. calcoaceticus BD413 was grown in a minimal medium that consisted of $60 \mathrm{~mm}$-lactic acid, $0.81 \mathrm{~mm}-\mathrm{MgSO}_{4}, 37 \mathrm{~mm}-\mathrm{NH}_{4} \mathrm{Cl}, 0.068 \mathrm{~mm}-\mathrm{CaCl}_{2}, 1.8 \mu \mathrm{M}-\mathrm{FeSO}_{4}$ and $40 \mathrm{~mm}$-potassium phosphate buffer of the required $\mathrm{pH}$ (in the range between 5 and 8 ). Cells were transformed either in the growth medium or, after transfer into fresh medium, at the indicated $\mathrm{pH}$.

EDTA treatment. Cells grown to the competent state, as described above, were collected by centrifugation, washed in $25 \mathrm{mM}$-MOPS/

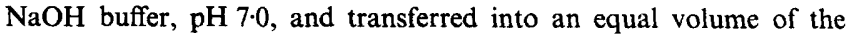
above buffer containing $0.5 \mathrm{~mm}$-EDTA. The cells were incubated for $30 \mathrm{~min}$ at $30^{\circ} \mathrm{C}$, collected, washed and transferred into the buffers indicated. The transformation efficiency was calculated using the transformation frequency of an untreated sample as a reference.

Inhibitor studies. The effect of dinitrophenol (DNP) on the transformation efficiency was assayed by growing cells to the competent state on LB-medium containing an additional $20 \mathrm{~mm}-\mathrm{KCl}$, using the standard procedure (see section on transformation). DNP was added to $0.5 \mathrm{ml}$ of cells, $10 \mathrm{~min}$ before addition of $2-4 \mu \mathrm{g}$ pAVA213-8 DNA. The cells were incubated with DNA for $60 \mathrm{~min}$ at $30^{\circ} \mathrm{C}$, after which $50 \mu \mathrm{g}$ DNAase I $\left(5 \mathrm{mg} \mathrm{ml}^{-1}\right)$ was added and an expression time of $1 \mathrm{~h}$ was allowed before plating on selective media. The effect of DNP on the growth rate of Acinetobacter was determined by diluting an overnight culture $1: 20$ into LB-medium, supplemented with $0,0 \cdot 5,1 \cdot 0,2.5$ or $5.0 \mathrm{~mm}$-DNP. Growth was determined by measuring the optical density at $540 \mathrm{~nm}$.

Identification of single-stranded DNA. Competent AAC400 cells $(20 \mathrm{ml})$ were incubated for $1.5 \mathrm{~h}$ with $8 \mu \mathrm{g}$ pAVA213-8 DNA at $30^{\circ} \mathrm{C}$. The bacteria were collected by centrifugation for $10 \mathrm{~min}$ at $12000 \mathrm{~g}$ and lysed in $8 \mathrm{ml} \mathrm{T}{ }_{50} \mathrm{E}_{20}(50 \mathrm{~mm}$-Tris/HCl, $20 \mathrm{~mm}$-EDTA, $\mathrm{pH} \mathrm{7 \cdot 6),350 \mu l}$ $30 \%(\mathrm{w} / \mathrm{v})$ Sarkosyl and $300 \mu \mathrm{l}$ proteinase $\mathrm{K}\left(10 \mathrm{mg} \mathrm{ml}^{-1}\right)$ for $30 \mathrm{~min}$ at $45^{\circ} \mathrm{C}$. The lysate was extracted three times with phenol/chloroform

Table 1. List of the bacterial strains and plasmids used in this study

\begin{tabular}{|c|c|c|}
\hline Strain/plasmid & Relevant genotype/phenotype & Source/reference \\
\hline A. calcoaceticus BD413 & Wild-type & Juni (1972) \\
\hline A. calcoaceticus BD413-ivl10 & Auxotrophic for IVL & Juni (1972) \\
\hline A. calcoaceticus AACl & $\operatorname{Rif}^{\mathrm{R}}$ & This study* \\
\hline A. calcoaceticus BD413-ivl10::pAVA213-8 & Auxotrophic for IVL, $\operatorname{Kan}^{\mathrm{R}}$ & This study $\dagger$ \\
\hline A. calcoaceticus AAC400 & recA::nptII & This study $\ddagger$ \\
\hline A. calcoaceticus AAC400-ivl10 & Auxotrophic for IVL, recA::nptII & Palmen et al. (1992) \\
\hline A. calcoaceticus AAC211 & Auxotrophic for IVL, com::nptII & Palmen et al. (1992) \\
\hline pGV1 & $\mathrm{Kan}^{\mathrm{R}}$ & Vosman et al. (1987) \\
\hline pWH1274 & $\mathrm{Amp}^{\mathrm{R}} \mathrm{Tet}^{\mathrm{R}}$ & Hunger et al. (1990) \\
\hline pAVA213-8 & $\mathrm{Amp}^{\mathrm{R}} \mathrm{Kan}^{\mathrm{R}}$ & Palmen et al. (1992) \\
\hline pAVA213-41 & $\mathrm{Amp}^{\mathrm{R}} \mathrm{Kan}^{\mathrm{R}}$ & This study \\
\hline
\end{tabular}

* Spontaneous rifampicin resistant mutant of $A$. calcoaceticus BD413.

† Obtained after transforming $A$. calcoaceticus BD413-ivl10 with pAVA213-8 and selection for kanamycin resistance.

$\ddagger$ Obtained via transfer of the $A$. calcoaceticus AAC400-ivl10 RecA mutation to $A$. calcoaceticus BD413. 
$(1: 1, \mathrm{v} / \mathrm{v})$ and once with chloroform/isoamylalcohol $(24: 1, \mathrm{v} / \mathrm{v})$. Subsequently, the DNA was precipitated with an ethanol/acetate mixture (96\% ethanol and $3 \mathrm{M}$-potassium acetate; $25: 1, \mathrm{v} / \mathrm{v})$ and dissolved in $200 \mu \mathrm{l} \mathrm{T}_{50} \mathrm{E}_{20}$. All DNA in this sample was purified by electrophoresis on a $0.8 \%$ agarose gel with single-stranded pAVA213-8 DNA as a marker. To concentrate and to get rid of RNA and some of the chromosomal DNA, fragments, between 2.5 and $11 \mathrm{~kb}$ in size, were isolated via electro-elution and after ethanol precipitation, resuspended in $20 \mu \mathrm{T}_{50} \mathrm{E}_{20}$ (single- and double-stranded pAVA213-8 runs in this size range). This fraction was re-run on a $0.8 \%$ agarose gel and transferred to nitrocellulose in $10 \times \mathrm{SSC}$, backed for $1 \mathrm{~h}$ at $80^{\circ} \mathrm{C}$ and analysed by Southern hybridization according to the protocol supplied by Boehringer Mannheim. pAVA213-8 DNA was used as a probe, after labelling with digoxigenin-dUTP, according to the manufacturer (Boehringer Mannheim).

Reproducibility. The quantitative reproducibility of the transformation data is affected by (i) the level of competence reached in the separate batches of cells used in the experiments, and (ii) the deviation between equally treated samples from the same competent culture. To provide some insight in the variation that exists between experiments, we calculated the mean and standard deviation of eleven transformations of $A$. calcoaceticus with pAVA213-8 DNA. The observed transformation frequencies ranged between $1.6 \times 10^{-2}$ and $9.9 \times 10^{-2}$, with a mean of $5.6 \times 10^{-2}$ and a standard deviation of $2.9 \times 10^{-2}$. The variation between transformation frequencies within one competent culture was much smaller. To demonstrate this, we analysed the transformation frequencies from five datapoints from one experiment (Fig. 4; pAVA213-8 DNA, from 2 to $20 \mu \mathrm{g} \mathrm{m}^{-1}$ ). The transformation frequencies ranged between $4.3 \times 10^{-3}$ and $5.6 \times 10^{-3}$, with a mean of $5.1 \times 10^{-3}$ and a standard deviation of $5.4 \times 10^{-4}$. Thus, the variability between experiments was much larger than within one experiment. For this reason we have chosen to present most of our data (Tables 4 to 7 ) as obtained from single representative experiments, rather than determining mean values and standard deviations from multiple experiments.

\section{Results}

Effect of DNA type and selection on transformation efficiency

To investigate the effect of different types of DNA and selection markers on the transformation efficiency of
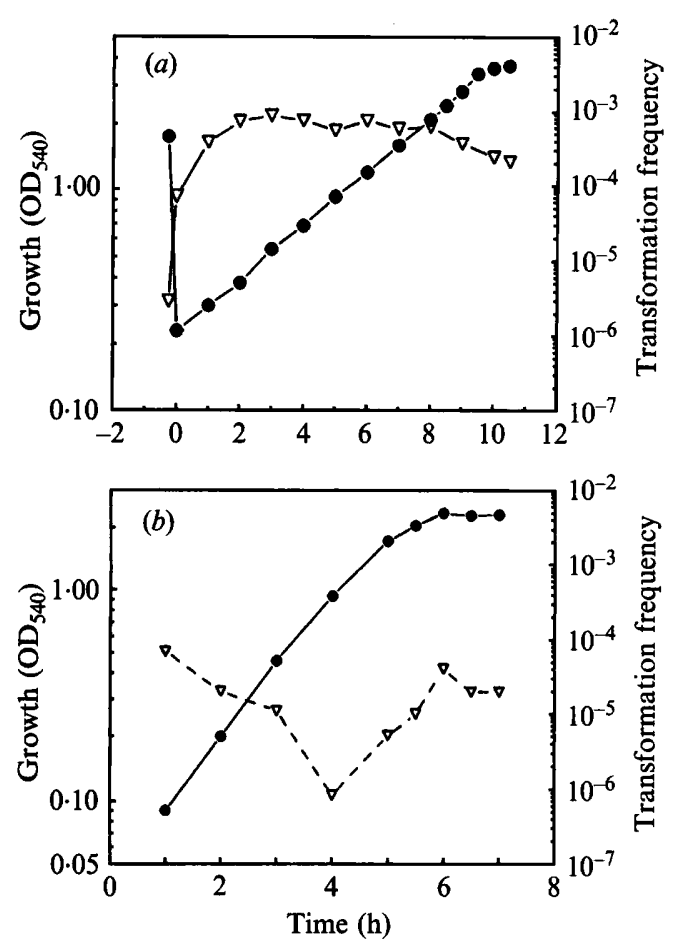

Fig. 1. Growth-phase dependence of transformation. (a) Strain BD413ivl10 was grown in mineral medium containing $10 \mu \mathrm{g}$ isoleucine, valine and leucine $\mathrm{ml}^{-1}$. Transformants were selected for IVL prototrophy. (b) Strain BD413 was grown on LB-medium. Transformants were selected for rifampicin resistance. The differences in growth medium and strains had no effect on the observed transformation frequencies. Growth; $\nabla$, transformation frequency. Panel $(a)$ was previously published in Molecular Microbiology 6, 1747-1754, and is reproduced here by permission of the publishers.

A. calcoaceticus, transformation experiments were performed using different types of DNA as listed in Table 2. From these results, it can be seen that when chromosomal DNA was used as transforming DNA and transformants were selected on the basis of resistance to kanamycin, rifampicin or prototrophy for IVL (using

Table 2. The different types of DNA and selection markers, used in the transformation efficiency experiments

The viable count in these experiments was in the order of $1 \times 10^{8}$ cells.

\begin{tabular}{llc}
\hline \multicolumn{1}{c}{ Description } & \multicolumn{1}{c}{ Selection } & $\begin{array}{c}\text { Transformation } \\
\text { frequency }\end{array}$ \\
\hline Chromosomal DNA from A. calcoaceticus AAC1 & Rifampicin resistance & $1 \cdot 1 \times 10^{-5}$ \\
Chromosomal DNA from A. calcoaceticus AAC1 & Prototrophy for IVL & $1 \cdot 5 \times 10^{-3}$ \\
Chromosomal DNA from A. calcoaceticus BD413- & Kanamycin resistance & $2 \cdot 2 \times 10^{-3}$ \\
ivl10::pAVA213-8 & & $9 \cdot 1 \times 10^{-2}$ \\
Plasmid pAVA213-8 & Kanamycin resistance & $1 \cdot 2 \times 10^{-4}$ \\
Plasmid pAVA213-8 & Kanamycin and ampicillin resistance & $1 \cdot 0 \times 10^{-3}$ \\
Plasmid pAVA213-41 & Kanamycin resistance & $7 \cdot 0 \times 10^{-5}$ \\
Single-stranded plasmid pAVA213-8 & Kanamycin resistance & $8 \cdot 4 \times 10^{-4}$ \\
Plasmid pGV1 & Kanamycin resistance & $2 \cdot 0 \times 10^{-3}$ \\
Plasmid pWH1274 & Ampicillin resistance & \\
\hline \hline
\end{tabular}


strain BD413-ivl10, auxotrophic for isoleucine, valine and leucine), selection for rifampicin resistance yielded transformation frequencies that were a factor of 100 lower than the transformation frequencies obtained with the other selection markers. Thus, the rifampicinresistance marker proved to be a poor selection marker when used in transformation experiments with Acinetobacter. This was also seen when the transformation efficiency of an Acinetobacter culture, using the rifampicin-resistance marker, was followed during growth in batch culture (Fig. 1). When the transformation frequency, used as an indicator for the level of competence for natural transformation, was monitored using selection for prototrophy for IVL, competence was induced at the onset of growth, after dilution of the overnight culture (Fig. 1a, adapted from Palmen et al., 1992). Competence remained maximal during the entire exponential growth-phase. This pattern of competence induction was also found using another auxotrophic marker (trpE27) and also with a kanamycin-resistance marker. The same experiment, using the rifampicin marker to monitor the competence level, yielded a different pattern (Fig. 1b). Competence seemed to be maximal at the onset of growth and at the transition from the exponential to the stationary phase. During exponential growth, the level of competence seemed to decrease. The explanation for these observations with the rifampicin marker is still unclear, but could be a result of an increased level of rifampicin sensitivity of $A$. calcoaceticus during exponential growth.

Transforming Acinetobacter with plasmid pGV1 (selection for kanamycin resistance) or pWH1274 (selection for ampicillin resistance) yielded transformation frequencies that were in the same range as those obtained with chromosomal DNA (Table 2). A large increase in the transformation frequency was obtained

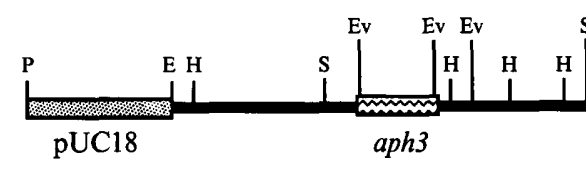

pAVA213-8

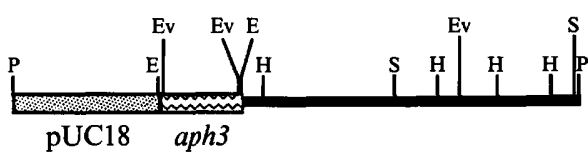

pAVA213-41

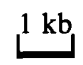

Fig. 2. Plasmid map of pAVA213-8 and pAVA213-41. E, EcoRI; Ev, EcoRV; H, HindIII; P, PstI; S, SalI. The restriction maps do not show all the HindIII sites that are present in these plasmids. when Acinetobacter was transformed with plasmid pAVA213-8 (Fig. 2). This is a pUC18-based plasmid, containing a $6.4 \mathrm{~kb}$ chromosomal DNA fragment from $A$. calcoaceticus in which an nptII gene (encoding kanamycin resistance) has been inserted (Palmen et al., 1992). pUC18-derived plasmids do not, or only very poorly, replicate in Acinetobacter. When Acinetobacter is transformed with pAVA213-8, kanamycin-resistant transformants originate only after insertion of the kanamycin marker into the chromosome. The insertion of the kanamycin marker is facilitated by the flanking chromosomal fragments and can take place in two ways: (i) via replacement recombination, resulting from homologous recombination events on both flanking sequences, or (ii) via a Campbell-like mode of insertion, resulting from a single recombination event. In the case of a Campbell-like integration, the entire plasmid will be integrated, whereas replacement recombination results in insertion of the kanamycin marker only. Transformants arising from a Campbell-like integration will be kanamycin and ampicillin resistant. Ampicillin resistance is encoded by the vector part of pAVA213-8 and will only be retained when the entire plasmid is integrated into the chromosome. Comparing the number of kanamycin-resistant transformants with kanamycin- and ampicillin-resistant transformants within one transformation experiment (Table 2) showed that replacement integration of the kanamycin marker of pAVA213-8 occurs 1000 times more frequently than Campbell-like integration.

To investigate which mode of integration is preferred, a new construct was devised, named pAVA213-41 (Fig. 2 ), in which the kanamycin-resistance gene is incorporated between the chromosomal insert of pAVA213-8 (without the kanamycin marker) and the vector part of the plasmid. Integration of the kanamycin marker of this construct into the recipient chromosome can only occur via a Campbell-like mechanism. Interestingly, transformation frequencies obtained with pAVA213-41 (Table 2) were about 50-100 times lower than with pAVA213-8. This indicates that replacement recombination is more efficient than Campbell-like integration.

To test whether single-stranded chromosomal Acinetobacter DNA could give rise to transformants, the chromosomal insert of pAVA213-8, containing the kanamycin marker, was cut out by restriction with Eco RI and Pst I, and subsequently denatured by heating for $10 \mathrm{~min}$ at $95^{\circ} \mathrm{C}$. Restriction of pAVA213-8 with these enzymes had no effect on the transformation efficiency (result not shown). Transformation with singlestranded DNA though (Table 2), resulted in a very much lower transformation frequency. The residual number of transformants is probably due to the presence of contaminating double-stranded copies, still present in 
Table 3. Transformation frequencies of Acinetobacter calcoaceticus BD413, grown in mineral medium containing different carbon sources and grown on $L B$ medium

Cultures were transformed with pAVA213-8 via the standard procedure and selected for kanamycin resistance.

\begin{tabular}{lc}
\hline \multicolumn{1}{c}{ Carbon source } & $\begin{array}{c}\text { Transformation } \\
\text { frequency }\end{array}$ \\
\hline Lactic acid $(60 \mathrm{~mm})$ & $1 \cdot 1 \times 10^{-2}$ \\
Glucose $(55 \mathrm{~mm})$ & $4.7 \times 10^{-2}$ \\
Ethanol $(1 \%)$ & $5.5 \times 10^{-2}$ \\
Hexadecane $(1 \%)$ & $0.9 \times 10^{-2}$ \\
Luria-Bertani medium & $5.5 \times 10^{-2}$ \\
\hline \hline
\end{tabular}

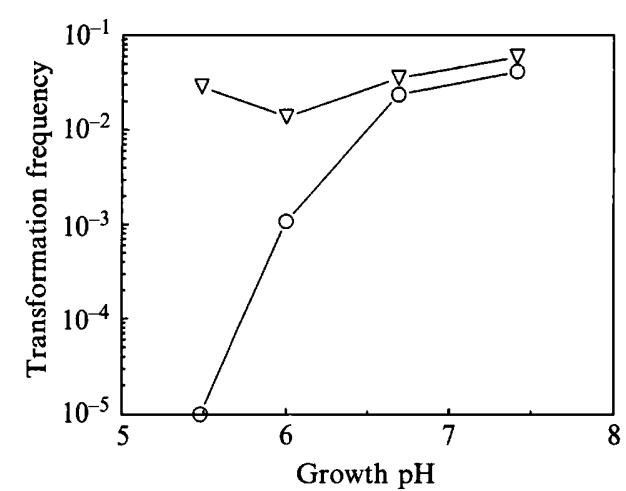

Fig. 3. $\mathrm{pH}$ dependence of the transformation efficiency of $A$. calcoaceticus BD413. A. calcoaceticus BD413 was grown and transformed in mineral medium supplemented with $40 \mathrm{~mm}$-potassium phosphate buffer of various $\mathrm{pH}$ values. The $\mathrm{pH}$ was determined at the time of sampling for the transformation assay. Samples were transformed at the culture $\mathrm{pH}(\mathrm{O})$, and, after transfer of the cells into standard fresh medium, were transformed at $\mathrm{pH} 6 \cdot 7,(\nabla)$.

the denatured DNA sample, although it cannot be excluded that some single-stranded DNA is taken up.

Growing A. calcoaceticus BD413 on different carbon sources had no effect on competence induction. From Table 3 it can be concluded that competence is induced to the same extent in minimal media supplemented with different carbon sources as well as in a rich medium. The selected carbon sources did not have a significant effect on competence induction. Also, the initial carbon source concentration, tested between 15 and 300 mm-lactic acid (result not shown), had no effect on competence induction in A. calcoaceticus BD413.

\section{Effect of $p H$ on competence induction}

A. calcoaceticus is capable of growing in a $\mathrm{pH}$ range from 5 to 8 . It is worthwile to see if competence is also induced during growth in this $\mathrm{pH}$ range. From Fig. 3 it can be seen that if cells are transformed when growing at a $\mathrm{pH}$ below 6.5 , the transformation frequency is reduced moderately at $\mathrm{pH} 6.0$ and severely at $\mathrm{pH} 5.4$. This does not mean that competence induction is inhibited at acidic $\mathrm{pH}$, since cells that are grown at acidic $\mathrm{pH}$ and subsequently transferred to a $\mathrm{pH}$ of 6.7 exhibit transformation frequencies comparable to cells grown at a neutral pH (Fig. 3). To exclude competence induction after transfer of the cells into the fresh medium at $\mathrm{pH} 6.7$, the complementary experiment was also performed. Cells were grown to competence at $\mathrm{pH} 7.0$ and transformed at $\mathrm{pH} 7 \cdot 0,6 \cdot 0$ and $5 \cdot 3$. Here also, a reduction of the transformation frequency was observed when the cells were transformed at an acidic $\mathrm{pH}$ (results not shown). Thus, below a $\mathrm{pH}$ of 6.5 , it is not competence induction that is inhibited, but the process of DNA uptake and/or integration.

\section{Effect of DNA concentration on transformation}

To study the relationship between the amount of DNA added and the efficiency of transformation, $A$. calcoaceticus was transformed with different concentrations of plasmid pGVl $(3.95 \mathrm{~kb})$ and pAVA213-8 $(10.5 \mathrm{~kb})$ DNA, and with chromosomal DNA from A. calcoaceticus BD413-ivl10::pAVA213-8. The results are shown in Fig. 4. The transformation frequency is plotted on a logarithmic scale because of the large dynamic range of five orders of magnitude in which the transformation process can be assayed. For clarity, an insert has been added in which the DNA concentrations are re-plotted logarithmically. It is clear that transformation follows saturation kinetics. Plasmid pGV1 DNA saturates above $20 \mu \mathrm{g}(\mathrm{ml} \text { cells })^{-1}$, whereas chromosomal DNA and plasmid pAVA213-8 saturate at approximately $1-2 \mu \mathrm{g}(\mathrm{ml} \text { cells })^{-1}$. This latter observation was to be expected since transformants resulting from pAVA213-8 and chromosomal DNA are

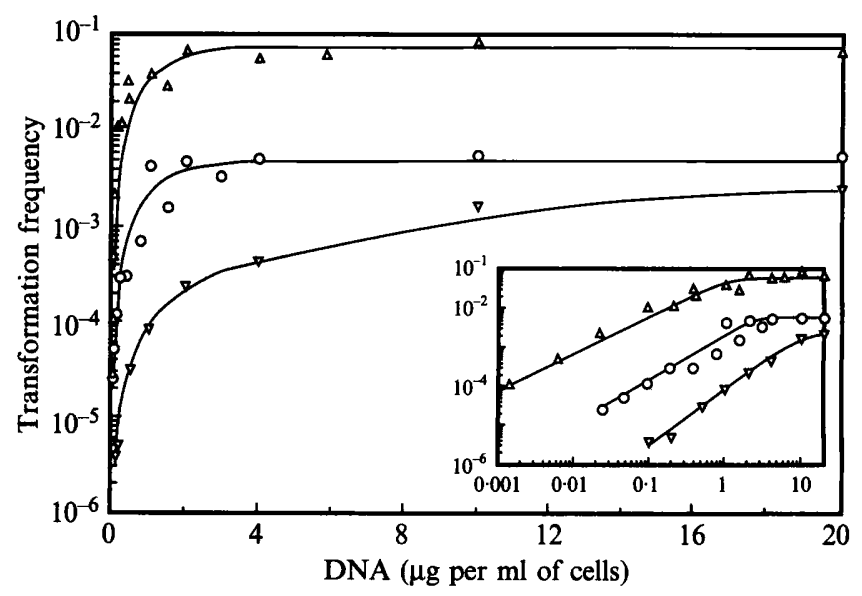

Fig. 4. Effect of increasing concentrations of chromosomal (O), pGV1 $(\nabla)$ and pAVA213-8 $(\triangle)$ DNA on transformation efficiency in $A$. calcoaceticus BD413. 
generated via the same mechanism. Both types of DNA are taken up via the same uptake system [see Effect of competing DNA on transformation efficiency (below) and Lorenz et al. (1992)], and both have to integrate their selective marker into the chromosome. The difference in the maximal level of transformation between chromosomal DNA and pAVA213-8 DNA can be explained by taking into account the ratio between DNA fragments selected for (i.e. containing the kanamycin marker) and competing fragments without the kanamycin marker. Plasmid pAVA213-8 contains, in addition to the kanamycin marker, $9 \mathrm{~kb}$ of DNA, whereas chromosomal DNA contains approximately $4000 \mathrm{~kb}$ of DNA per kanamycin marker (the exact size of the chromosome has not been determined yet). Thus, pAVA213-8 contains more copies of the selective marker per $\mu$ g DNA than chromosomal DNA, resulting in an increased maximal transformation frequency.

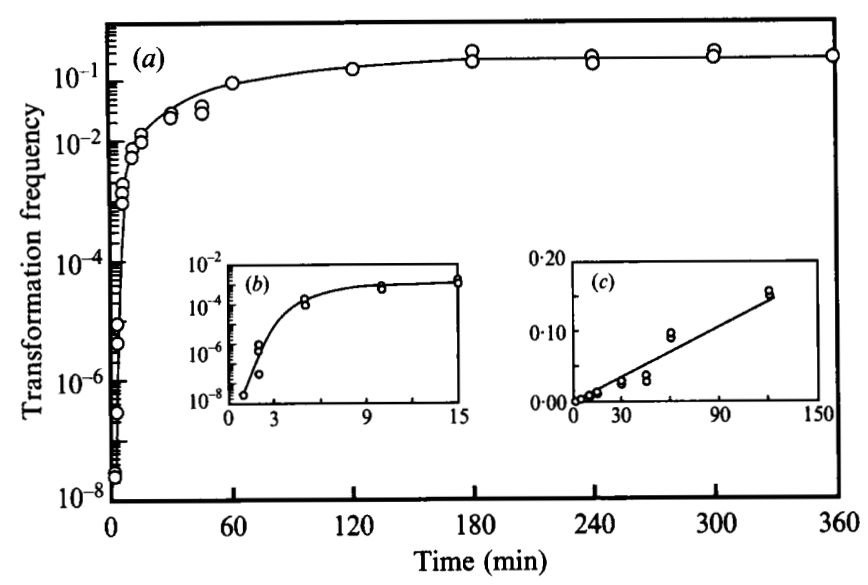

Fig. 5. Transformation frequency of $A$. calcoaceticus BD413 as a function of the incubation time with pAVA213-8 DNA. (a), (b) and (c) are referred to in the text.
Transformation as a function of the length of the incubation period with plasmid DNA

To obtain more information about DNA uptake as a function of incubation time, Acinetobacter was transformed with pAVA213-8 and transformation was interrupted by addition of DNAase I, at various times after addition of DNA (Fig. 5). When DNAase I was added before addition of DNA, no transformants were found upon selection for kanamycin resistance. The first transformants are already present after incubation for $1 \mathrm{~min}$ (Fig. $5 b$; note that the figure is a logarithmic plot). The number of transformants increased linearly up to incubation for $2 \mathrm{~h}$ (Fig. $5 \mathrm{c}$ ) before transformation saturated. After $3 \mathrm{~h}$, about $25 \%$ of the cells in the culture had been transformed to kanamycin resistance (Fig. $5 a$ ).

\section{Effect of divalent cations on transformation}

In Bacillus subtilis (Mulder \& Venema, 1982a,b), Streptococcus pneumoniae (Lacks et al., 1975) and Azotobacter vinelandii (Page \& von Tigerstrom, 1979), transformation is dependent on the presence of $\mathrm{Mg}^{2+}$ and/or $\mathrm{Ca}^{2+}$ ions. After treatment of A. calcoaceticus with EDTA, to remove divalent cations, transformation was severely inhibited (Table 4). Addition of $5 \mathrm{~mm}-\mathrm{Mg}^{2+}$ partially restored transformation up to $3 \%$ of the wildtype level. Addition of $5 \mathrm{~mm}-\mathrm{Ca}^{2+}$ or $0.5 \mathrm{~mm}-\mathrm{Mn}^{2+}$ restored transformation to $1 \%$. Simultaneous addition of $5 \mathrm{mM}-\mathrm{Mg}^{2+}$ and $5 \mathrm{mM}-\mathrm{Ca}^{2+}$ restored transformation up to $7 \%$. If EDTA-treated cells were resuspended in minimal medium without a carbon source, transformation was restored up to $7.7 \%$. The minimal medium contains $0.81 \mathrm{mM}-\mathrm{Mg}^{2+}$ and $0.068 \mathrm{~mm}-\mathrm{Ca}^{2+}$. This indicates that at $5 \mathrm{mM}, \mathrm{Mg}^{2+}$ and $\mathrm{Ca}^{2+}$ were present at saturating concentrations. When EDTA-treated cells were suspended in LB-medium, transformation was

Table 4. Effect of divalent cations on transformation

$100 \%$ efficiency represents a transformation frequency of $1.3 \times 10^{-2}$.

\begin{tabular}{clc}
\hline $\begin{array}{c}\text { EDTA } \\
\text { treatment }\end{array}$ & \multicolumn{1}{c}{ Resuspended in: } & $\begin{array}{c}\text { Transformation } \\
\text { efficiency (\%) }\end{array}$ \\
\hline no & Mineral medium & 100 \\
yes & MOPS buffer & $0 \cdot 1$ \\
yes & MOPS buffer $+5{\mathrm{mM}-\mathrm{MgCl}_{2}}^{2}$ & $3 \cdot 3$ \\
yes & MOPS buffer $+5 \mathrm{mM}-\mathrm{CaCl}_{2}$ & $1 \cdot 2$ \\
yes & MOPS buffer $+5 \mathrm{mM}-\mathrm{MgCl}_{2}+5 \mathrm{mM}-\mathrm{CaCl}_{2}$ & $7 \cdot 0$ \\
yes & MOPS buffer $+0.5 \mathrm{mM}-\mathrm{MnCl}_{2}$ & $1 \cdot 1$ \\
yes & MOPS buffer $+0.5 \mathrm{mM}-\mathrm{ZnCl}_{2}$ & $0 \cdot 004$ \\
yes & MOPS buffer $+0.5 \mathrm{mM}-\mathrm{CuCl}_{2}$ & No viable count \\
yes & Mineral medium without lactic acid & $7 \cdot 7$ \\
yes & Mineral medium with lactic acid & $8 \cdot 5$ \\
yes & LB medium & 31 \\
\hline
\end{tabular}


restored up to $31 \%$ of the original level. The effect of divalent cations on transformation was studied in MOPS buffer without addition of an energy source. To test whether supplying an energy source could explain the improved transformation in LB-medium, cells were treated with EDTA and resuspended in minimal medium containing $60 \mathrm{~mm}$-lactic acid. The resulting transformation frequency of $8.5 \%$ was comparable to the value obtained after resuspending the cells in minimal medium without a carbon source. This indicates that after treatment with EDTA and resuspending the cells in MOPS buffer, transformation is not limited by a lack of energy. The factor responsible for the extra restoration of transformation in LB-medium has not yet been identified. Another interesting observation was that addition of $0.5 \mathrm{~mm}-\mathrm{Zn}^{2+}$ specifically inhibited transformation. $\mathrm{Zn}^{2+}$ might be of use as a specific inhibitor of transformation. Addition of $0.5 \mathrm{~mm}-\mathrm{Cu}^{2+}$ to EDTAtreated cells proved to be toxic for the cells as it severely reduced the viable count.

\section{Effect of energization of competent cells on the transformation efficiency}

It is generally assumed that DNA uptake during natural transformation is an energy-requiring process (Grinius, 1987). Growing Acinetobacter in the presence of different concentrations of dinitrophenol (DNP), a compound that dissipates the protonmotive force, showed that growth is moderately inhibited at a concentration of $1 \mathrm{~mm}$ and completely inhibited at $2.5 \mathrm{~mm}$-DNP (Table 5). When DNP was added to a competent culture (grown to competence via the standard procedure in LB-medium) 10 min before addition of DNA, transformation was inhibited at DNP concentrations higher than $1 \mathrm{mM}$ (Table 5). This shows that energy supply, in the presence of $1 \mathrm{~mm}-\mathrm{DNP}$, becomes limiting for both growth and transformation, with growth being more sensitive. The energy requirement of transformation could also be demonstrated with the protonophores 5-chloro-3-tertbutyl-2'-chloro-4'-nitrosalicylanilide (S13) and 3,5-ditert-butyl-4-hydroxybenzilidene malononitrile (SF6847; data not shown).

Table 5. Effect of DNP on transformation frequency and growth of Acinetobacter calcoaceticus BD413

\begin{tabular}{cccc}
\hline \hline $\begin{array}{c}\text { DNP } \\
\text { concn (mM) }\end{array}$ & $\begin{array}{c}\text { Growth } \\
\text { rate }\left(\mathrm{h}^{-1}\right)\end{array}$ & Final OD $_{540}$ & $\begin{array}{c}\text { Transformation } \\
\text { frequency }\end{array}$ \\
\hline No addition & 0.83 & 2.9 & $1.6 \times 10^{-2}$ \\
0.5 & 0.79 & 2.5 & $1.9 \times 10^{-2}$ \\
1.0 & 0.52 & 1.8 & $1.0 \times 10^{-2}$ \\
2.5 & & No growth & $5.5 \times 10^{-5}$ \\
5.0 & \multicolumn{2}{c}{ No growth } & $1.9 \times 10^{-5}$ \\
\hline \hline
\end{tabular}

Table 6. Effect of competing chromosomal DNA on efficiency of transformation with plasmid pGVI DNA

\begin{tabular}{lcc}
\hline \hline \multicolumn{1}{c}{ Competing DNA } & $\begin{array}{c}\text { Transformation } \\
\text { frequency }\end{array}$ & Efficiency (\%) \\
\hline None & $7 \cdot 1 \times 10^{-4}$ & 100 \\
$0.5 \mu \mathrm{g} A$. calcoaceticus & $2.3 \times 10^{-5}$ & 32.4 \\
$2.0 \mu \mathrm{g}$ A. calcoaceticus & $7 \cdot 7 \times 10^{-6}$ & 10.8 \\
$5.0 \mu \mathrm{g} A$. calcoaceticus & $4.7 \times 10^{-6}$ & 6.7 \\
$10.0 \mu \mathrm{g}$ A. calcoaceticus & $1.6 \times 10^{-6}$ & 2.2 \\
$10.0 \mu \mathrm{g} P$. stutzeri & $1.6 \times 10^{-6}$ & 2.2 \\
& & \\
\hline
\end{tabular}

\section{Effect of competing DNA on transformation frequency}

Acinetobacter is capable of transformation using both chromosomal and plasmid DNA. To tackle the question whether or not both types of DNA are transported via the same uptake system, Acinetobacter was transformed with plasmid pGV1 in the presence of different concentrations of chromosomal Acinetobacter DNA. The transformation frequencies resulting from uptake and maintenance of pGV1 were monitored (Table 6). Transformation with $2 \mu \mathrm{g}$ pGV1, without addition of chromosomal DNA, was used as a reference. Increasing amounts of chromosomal Acinetobacter DNA resulted in decreasing transformation frequencies with pGV1. This means that chromosomal DNA and plasmid DNA compete for the same uptake system. Due to the difference in fragment length of chromosomal (a large range of sizes) and pGV1 $(3.95 \mathrm{~kb})$ DNA, addition of $2 \mu \mathrm{g}$ chromosomal DNA to $2 \mu \mathrm{g}$ plasmid DNA does not result in a $50 \%$ inhibition of transformation. When chromosomal DNA from Pseudomonas stutzeri was used as competing DNA, the same level of inhibition of transformation with pGV1 was observed. This indicates that Acinetobacter does not discriminate between homologous and heterologous DNA at the stage of binding and uptake. Similar results were obtained by Lorenz $e t$ al., 1992.

\section{Effect of DNA topology}

Whether or not DNA in Acinetobacter is translocated in a single- or double-stranded form has yet to be determined, and this issue is still rather controversial for other Gram-negative bacteria (Doran et al., 1987; Goodgal, 1982). One way to obtain more information about this process is to investigate the effects of plasmid topology on transformation. When undigested pGV1 DNA was used as transforming DNA, the transformation frequency was $8.4 \times 10^{-4}$ (Table 7). Transformation with monomers of pGV1 gave the same efficiency of transformation as a mixture of mono- and multimers (data not shown). This means that transformation with 
Table 7. Effect of plasmid topology on transformation efficiency with plasmid $p G V 1$

\begin{tabular}{llcc}
\hline \hline \multicolumn{1}{c}{ Plasmid form } & Topology & $\begin{array}{c}\text { Transformation } \\
\text { frequency }\end{array}$ & Efficiency (\%) \\
\hline Undigested & & $5.4 \times 10^{-4}$ & 100 \\
SmaI digested $(2 \mu \mathrm{g})$ & Blunt & $1.2 \times 10^{-6}$ & 0.23 \\
Pst I digested $(2 \mu \mathrm{g})$ & 3' Overhang & $5.8 \times 10^{-7}$ & 0.11 \\
EcoRI digested $(2 \mu \mathrm{g})$ & 5' Overhang & $4.0 \times 10^{-7}$ & 0.074 \\
ClaI digested $(2 \mu \mathrm{g})$ & 5' Overhang & $8.5 \times 10^{-8}$ & 0.016 \\
EcoRI digested $(1.0 \mu \mathrm{g})+$ & & $3.2 \times 10^{-5}$ & 3.7 \\
ClaI digested $(1.0 \mu \mathrm{g})$ & & & \\
\hline \hline
\end{tabular}

plasmid DNA in Acinetobacter is not dependent on the presence of multimers, as in Bacillus subtilis (Canosi et al., 1978; de Vos et al., 1981). When pGV1 was restricted with EcoRI or ClaI (creating 5' overhanging ends), PstI (creating $3^{\prime}$ overhanging ends) or SmaI (creating blunt ends), transformation was severely inhibited (pGV1 has a unique restriction site for each of these enzymes). When, on the other hand, a mixture of plasmids was used, restricted with different enzymes (i.e. EcoRI and ClaI), transformation could be partially restored. The EcoRI and ClaI site are oppositely located in the intact plasmid. Recircularization of the EcoRI-digested plasmid after transformation is most likely facilitated by a ClaI-digested copy of the plasmid and vice versa. The second copy allows closure of the restriction site generated by the first enzyme, resulting in a partially double-stranded plasmid, which can be repaired by the enzymic machinery of the host cell. From these results, it is not certain yet whether DNA enters in single- or in double-stranded form. If plasmid DNA were to enter single-strandedly, recircularization would be promoted by homologous base-pairing of the single-stranded DNA, bridging the two restriction sites. On the other hand, multiple plasmid DNA fragments entering linearly in a double-stranded fashion could recircularize via homologous recombination. The latter possibility implies that plasmids are not able to transform a recombinationdeficient strain. However, a previously constructed RecA-deficient $A$. calcoaceticus strain AAC400 (derived from BD413) displayed almost wild-type transformation frequencies with plasmid DNA. The transformation frequency of $A$. calcoaceticus BD413 obtained with plasmid pWH1274 was $2.0 \times 10^{-3}$, whereas for AAC400 a value of $5.7 \times 10^{-4}$ was obtained. This proves that plasmid recircularization is a RecA-independent mechanism and suggests, together with the results given above, that DNA enters in a single-stranded fashion.

To prove that transforming DNA is taken up singlestrandedly, the following experiment was devised (adapted from Stachel et al., 1986). The RecA-deficient Acinetobacter strain (AAC400-ivl10, Palmen et al., 1992) was incubated with pAVA213-8 DNA. Subsequently, DNA was extracted from these cells, electrophoresed and blotted under non-denaturing conditions onto a nitrocellulose filter. Under these conditions only singlestranded DNA or double-stranded DNA to which protein is bound, is transferred to the filter. The filter was

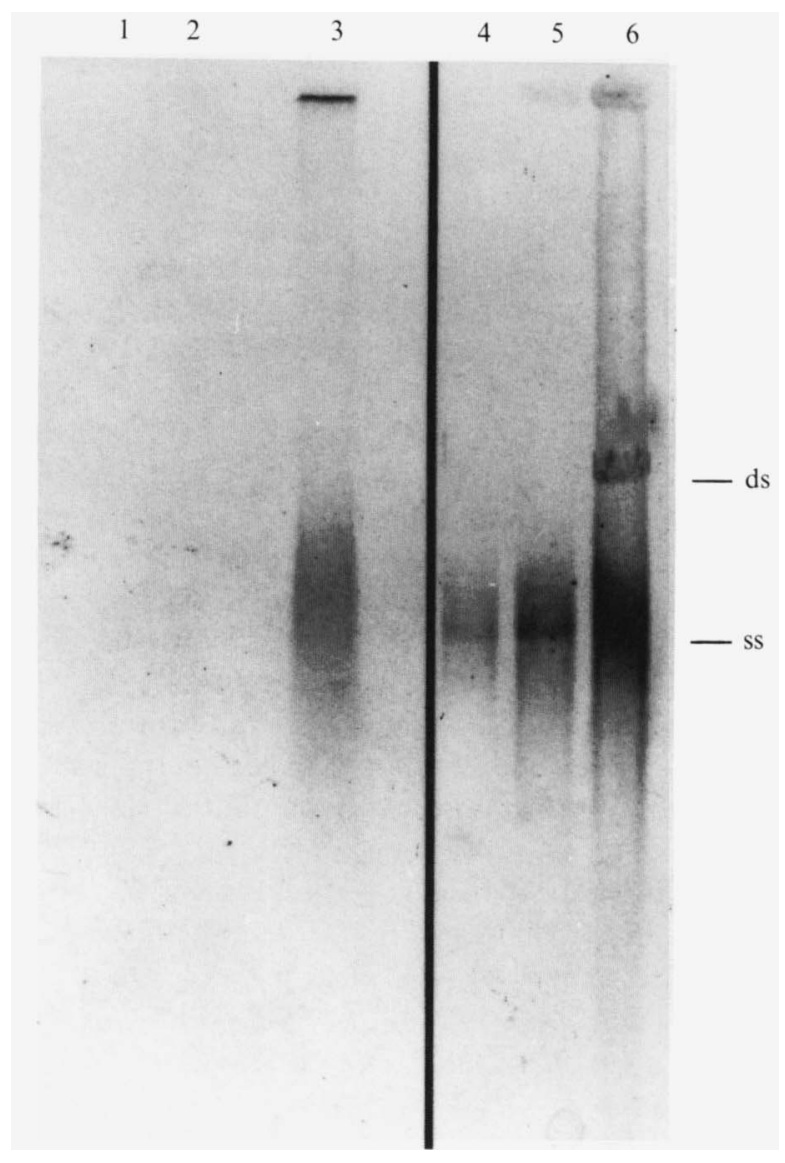

Fig. 6. Southern hybridization of $A$. calcoaceticus AAC400-ivl10 DNA transformed with pAVA213-8 DNA. Lane 1, non-transformed AAC400-ivl10; lane 2, AAC211 transformed with pAVA213-8; lane 3, AAC400-ivl10 transformed with pAVA213-8; lane 4, 50 ng singlestranded pAVA213-8; lane 5, 200 ng single-stranded pAVA213-8; lane 6, $1000 \mathrm{ng}$ single-stranded pAVA213-8. ss, Single-stranded pAVA213-8; ds, double-stranded pAVA213-8. 
subsequently hybridized, using pAVA213-8 DNA as a probe. In lanes 4,5 and 6 of Fig. 6, single-stranded pAVA213-8 DNA (respectively 50, 200 and $1000 \mathrm{ng}$ ) was layered as a positive control. In lane 6 , a hybridization band of double-stranded pAVA213-8 can be observed also, probably because of the large amount of DNA that was blotted. This signal is not visible in lanes 4 and 5. In lane 3, containing DNA extracted from AAC400-ivl10 after incubation with pAVA213-8, a clear hybridizing signal is present. This signal is absent in lane 1, which contained DNA from an AAC400-ivl10 culture that had not been incubated with pAVA213-8 DNA.

One could argue that the hybridizing material originated directly from the added DNA. This is unlikely, however, because the plasmid DNA used was purified via equilibrium centrifugation in a caesium chloride gradient and no single-stranded DNA could be detected in that sample. To further check whether the signal observed in lane 3 is transformation related, strain AAC211, a transformation-deficient mutant (Palmen et al., 1992) of strain BD413-ivl10, was incubated with pAVA213-8. DNA extracted from AAC211 after incubation, was layered in lane 2 . From these cells, no hybridizing DNA could be extracted. These results lead to the conclusion that the signal observed really represents single-stranded DNA present inside the cells. Thus, the incoming DNA is converted into a singlestranded form during uptake for natural transformation in $A$. calcoaceticus.

\section{Discussion}

The main characteristic of genetic transformation is the change in genotype of the recipient organism after incorporation, or in the case of plasmid DNA, replication, of the DNA taken up. To be able to detect transformation via a change in genotype, a clearly selectable marker is a prerequisite. Our first experiments were devised to optimize the selection marker and the kind of DNA (chromosomal or plasmid DNA) bearing the marker. From these experiments, we concluded that rifampicin resistance is a very poor marker for use in $A$. calcoaceticus. The maximal transformation frequencies with this marker are low and activity seems to be dependent on the growth phase of the culture (Fig. 1). A large increase in transformation efficiency was obtained when plasmid pAVA213-8, containing a kanamycinresistance marker flanked by Acinetobacter sequences, was used as transforming DNA. Compared to transformations with other plasmids like pGV1, pWH1274 or pKT210 (not shown), pAVA213-8 yields transformation frequencies that are about 50 times higher. pAVA213-8 does not replicate in Acinetobacter and the kanamycin-resistance marker must recombine into the chromosome to be able to transform Acinetobacter into a kanamycin-resistant state. Integration of the kanamycin-resistance gene is facilitated by the flanking Acinetobacter sequences. From the transformation frequencies obtained with plasmid pAVA213-8, pGV1 and $\mathrm{pWH} 1274$, one has to conclude that the process of integration of the marker into the chromosome via homologous recombination is much more efficient than the process of plasmid recircularization. This effect can also be seen in the experiment on the affinity of transformation for chromosomal and plasmid DNA (Fig. 4). Uptake of a plasmid that has to recircularize in order to be propagated saturates at much higher DNA concentrations than uptake of pAVA213-8 or chromosomal DNA. Chromosomal DNA is often used in transformation assays of naturally transformable bacteria. The use of pAVA213-8-like transformation constructs may increase the observed maximal transformation frequencies in these organisms too.

The main purpose of this investigation was to determine basic characteristics of natural transformation in Acinetobacter and to compare this transformation system with the systems reported in other Gram-negative (Haemophilus and Neisseria) and Gram-positive (Bacillus and Streptococcus) bacteria. From the competition experiments, it is concluded that plasmid DNA and chromosomal DNA are taken up via the same system and that Acinetobacter does not discriminate between heterologous and homologous DNA. This is also found for the transformation systems of the Gram-positive genera Bacillus and Streptococcus, and differs from the transformation system of Haemophilus and Neisseria, which both discriminate between heterologous and homologous DNA via specific sequences present on their DNA (Goodgal, 1982; Goodman \& Scocca, 1991). From our inhibitor studies we can conclude that natural transformation is an energy-requiring process in Acinetobacter, as it is in Bacillus and Streptococcus (Grinius, 1987). Our data indicate that growth is more sensitive to dissipation of the protonmotive force than transformation (Table 5).

DNA transport across the cytoplasmic membrane in natural transformation occurs in a single-stranded fashion in Bacillus (Piechowska \& Fox, 1971 ; DavidoffAbelson \& Dubnau, 1973), and Streptococcus (Morrison \& Guild, 1973) and possibly also in Haemophilus (Kahn et al., 1983). We have shown here that this is also the case in Acinetobacter. From the hybridization experiment, one can conclude that DNA is taken up in a singlestranded fashion. The hybridizing signal in lane 3, representing single-stranded pAVA213-8, is rather broad and is not contained in a single sharp band; neither are the single-stranded controls. This could be the result of one or more of a number of factors. (i) The plasmid was 
taken up only partially, leading to an array of plasmid sizes present in the extracted DNA. (ii) Mechanical shear during the phenol/chloroform extraction steps could fracture the DNA, again leading to smaller fragments. (iii) Re-hybridization of the single-stranded fragments during the isolation procedure could lead to increased fragment sizes. (iv) The formation of secondary structure could occur, leading to unpredictable electrophoretic behaviour. (v) Single-stranded nicks present in the pAVA213-8 DNA could give rise to an array of fragment sizes after denaturation of the DNA. Since chromosomal and plasmid DNA are taken up via the same system, both will enter the cell single-strandedly. This is in agreement with the results of the plasmid topology experiments, which suggested the conversion of doublestranded into single-stranded DNA during uptake. This probably also explains why integration via replacement recombination is favoured over Campbell-like integration. After uptake, a closed circular doublestranded plasmid is converted into a linear singlestranded DNA molecule. In the case of pAVA213-41, integration of the entire plasmid can occur only after recircularization of the plasmid and a subsequent homologous recombination event. Recircularization can be promoted by the resident chromosome, provided the plasmid was linearized during uptake in the Acinetobacter fragment of pAVA213-41. Or, if the plasmid was linearized in the vector part or the kanamycin-resistance gene of the plasmid, it can recircularize via a second copy of the plasmid restricted at a separate site. This process of recircularization is not necessary in the case of integration via replacement recombination. The incoming single-stranded DNA molecule of pAVA213-8 can directly pair with the resident chromosome and integrate via two RecAdependent recombination events, provided that the plasmid was not linearized within about $1 \mathrm{~kb}$ of the kanamycin-resistance marker. The process of recircularization has a lower efficiency than the process of homologous recombination, as shown in the saturation experiment with chromosomal and plasmid DNA (Fig. 4).

Bacillus subtilis and Streptococcus pneumoniae are capable of binding single- and double-stranded DNA (Smith et al., 1985; Lacks, 1977), but only doublestranded DNA is capable of transforming these organisms (Rudolph et al., 1986; Lacks, 1962). During uptake, one of the strands of the DNA helix is degraded by membrane-bound nucleases and the complementary strand is internalized (Lacks et al., 1975; Lacks \& Neuberger, 1975). Uptake of DNA is inhibited after removal of divalent cations by EDTA treatment. $\mathrm{Mg}^{2+}$ proved to be necessary for the correct function of the membrane-bound nucleases (Lacks et al., 1975; Mulder
\& Venema, $1982 a, b)$, whereas $\mathrm{Ca}^{2+}$ is additionally required for uptake of DNA in S. pneumoniae (Seto \& Tomasz, 1976). Transformation of Haemophilus, on the other hand, is not inhibited after EDTA treatment (Noteborn et al., 1981). Transformation in Acinetobacter also shows a requirement for $\mathrm{Mg}^{2+}$ and/or $\mathrm{Ca}^{2+}$ and/or $\mathrm{Mn}^{2+}$. From this, combined with the fact that DNA enters Acinetobacter in a single-stranded form, we expect the involvement of a membrane-located nuclease in DNA uptake during natural transformation in Acinetobacter too.

From Fig. 5, an approximate DNA uptake rate can be calculated. pAVA213-8 is a plasmid of $10.5 \mathrm{~kb}$. The first transformants arise within $1 \mathrm{~min}$ of incubation with DNA. The minimum DNA fragment size needed to transform Acinetobacter into a kanamycin-resistant form is about $3.5 \mathrm{~kb}$. The kanamycin marker is $1.4 \mathrm{~kb}$ and about $1 \mathrm{~kb}$ of flanking homologous sequences on each side of the marker are needed for integration into the chromosome (R. Palmen and others, unpublished results; L. A. Gregg-Jolly \& L. N. Ornston, unpublished results). Thus, at least $3.5 \mathrm{~kb}$ had to be taken up in $1 \mathrm{~min}$ to give rise to a kanamycin-resistant transformant. This results in a minimal uptake rate of about 60 nucleotides $\mathrm{s}^{-1}$. This value does not include the time required for binding and therefore is an underestimate. This rate is comparable with uptake rates determined for Bacillus and Streptococcus which are in the order of 80-180 nucleotides s ${ }^{-1}$ (Grinius, 1987; Dubnau, 1991). Uptake rates in Haemophilus are much higher (500-30000 nucleotides $\mathrm{s}^{-1}$; Grinius, 1987). The high nucleotide uptake rate and EDTA-insensitivity of transformation in Haemophilus is probably due to the specific uptake mechanism via so called transformasomes (Kahn et al., 1982). A transformasome is a vesicle-like structure at the surface of the cell envelope. These vesicles can bind double-stranded DNA and are subsequently transported from the outer to the inner membrane, where the DNA is released into the cytoplasm. DNA uptake via transformasomes has only been detected in Haemophilus so far.

With respect to the above-mentioned properties, the transformation system of Acinetobacter does not resemble the transformation system studied in species of the Gram-negative genera Haemophilus or Neisseria. On the contrary, it is more similar to the systems in Bacillus and Streptococcus. Differences between 'the Grampositive system' and the Acinetobacter system are mainly restricted to the regulation of competence development. No competence factor has been detected in Acinetobacter (Juni, 1978), in contrast to Streptococcus. Competence in A. calcoaceticus BD413 is maximal in the exponential growth-phase (Fig. 1). It is not as strictly regulated as competence induction in a number of other organisms, 
which induce competence only under specific growth conditions. Competence induction in $A$. calcoaceticus BD413 seems to be independent of the growth medium and $\mathrm{pH}$. Further studies will be adressed to the regulation of competence induction and to the nature of the mechanism of uptake of DNA and the energization of this process.

We thank M. G. Lorenz, L. A. Gregg-Jolly and L. N. Ornston for sharing observations prior to publication.

\section{References}

Ahlquist, E. F., Fewson, C. A., Ritchie, D. A., Podmore, J. \& RowELl, V. (1980). Competence for genetic transformation in Acinetobacter calcoaceticus NCIB8250. FEMS Microbiology Letters 7, 107-109.

Avery, O. T., McLeod, C. M. \& McCarthy, M. (1944). Studies on the chemical nature of the substance inducing transformation of pneumococcal types. Journal of Experimental Medicine 79, 137158.

Canosi, U., Morelli, G. \& Trautner, T. A. (1978). The relationship between molecular structure and transformation efficiency of some $S$. aureus plasmids isolated from B. subtilis. Molecular and General Genetics 166, 259-267.

Davidoff-Abelson, R. \& Dubnau, D. (1973). Kinetic analysis of the products of donor deoxyribonucleate in transformed cells of Bacillus subtilis. Journal of Bacteriology 116, 154-162.

Doran, J. L., Bingle, W. H., Roy, K. L., Hiratsuka, K. \& Page, W. J. (1987). Plasmid transformation of Azotobacter vinelandii OP. Journal of General Microbiology 133, 2059-2072.

DuBNAU, D. (1991). Genetic competence in Bacillus subtilis. Microbiological Reviews 55, 395-424.

GoODGAL, S. H. (1982). DNA uptake in Haemophilus transformation. Annual Review of Genetics 16, 169-192.

GoOdmAN, S. D. \& SCOCCA, J. J. (1991). Identification and arrangement of the DNA sequence recognized in specific transformation of Neisseria gonorrhoeae. Proceedings of the National Academy of Sciences of the United States of America 85, 6982-6986.

GRINIUS, L. (1987). Bioenergetics of nucleic acid transport. In Energy Transduction and Gene Transfer in Chemotrophic Bacteria, chapter 6, pp. 161-215. Chur, Switzerland: Harwood Academic Publishers.

Hunger, M., SChMucker, R., Kishan, V. \& Hillen, W. (1990). Analysis and nucleotide sequence of an origin of DNA replication in Acinetobacter calcoaceticus and its use for Escherichia coli shuttle plasmids. Gene 87, 45-51.

IsH-HoRowicz, D. \& BURKE, F. J. (1981). Rapid and efficient cosmid cloning. Nucleic Acids Research 9, 2989-2999.

JUNI, E. (1972). Interspecies transformation of Acinetobacter: genetic evidence for a ubiquitous genus. Journal of Bacteriology 112, 917-931.

JUNI, E. (1974). Simple genetic transformation assay for rapid diagnosis of Moraxella osloensis. Applied Microbiology 27, 16-24.

JUNI, E. (1978). Genetics and physiology of Acinetobacter. Annual Review of Microbiology 32, 349-371.

JUNI, E. \& JANIK, A. (1969). Transformation of Acinetobacter calcoaceticus (Bacterium anitratum). Journal of Bacteriology 98, 281288.

Kahn, M. E., Maul, S. H. \& Goodgal, S. H. (1982). Possible mechanisms for donor DNA binding and transport in Haemophilus. Proceedings of the National Academy of Sciences of the United States of America 79, 6370-6374.

KAHN, M. E., BaRANY, F. \& SMITH, H. O. (1983). Transformasomes: specialized membranous structures that protect DNA during Haemophilus transformation. Proceedings of the National Academy of Sciences of the United States of America 80, 6927-6931.
LACKs, S. (1962). Molecular fate of DNA in genetic transformation of Pneumococcus. Journal of Molecular Biology 5, 119-131.

LACKS, S. (1977). Binding and entry of DNA in bacterial transformation. In Microbial Interactions, pp. 179-232. Edited by J. L. Reissig. London: Chapman \& Hall.

LACKS, S. \& NeUBERgER, M. (1975). Membrane location of a deoxyribonuclease implicated in genetic transformation of Diplococcus pneumoniae. Journal of Bacteriology 124, 1321-1329.

LaCks, S., GreenberG, B. \& NeUberger, M. (1975). Identification of a deoxyribonuclease implicated in genetic transformation of Diplococcus pneumoniae. Journal of Bacteriology 123, 222-232.

LORENZ, M. G., REIPSChLÄGER, K. \& WACKERNAGEL, W. (1992). Plasmid transformation of naturally competent Acinetobacter calcoaceticus in non-sterile soil extract and groundwater. Archives of Microbiology 157, 355-360.

Maniatis, T., Fritsch, E. F. \& SAmbrook, J. (1982). Molecular cloning: A Laboratory Manual. Cold Spring Harbor, NY: Cold Spring Harbor Laboratory.

MoRRISON, D. A. \& GUILD, W. R. (1973). Breakage prior to entry of donor DNA in pneumococcus transformation. Biochimica et Biophysica Acta 299, 545-556.

Mulder, J. A. \& Venema, G. (1982a). Isolation and partial characterization of Bacillus subtilis mutants impaired in DNA entry. Journal of Bacteriology 150, 260-268.

Mulder, J. A. \& VENEMA, G. (1982 $b$ ). Transformation-deficient mutants of Bacillus subtilis impaired in competence-specific nuclease activities. Journal of Bacteriology 152, 166-174.

Noteborn, M., Venema, G. \& Kooistra, J. (1981). Effect of ethylenediamine-tetraacetic acid on deoxyribonucleic acid entry and recombination in transformation of a wild-type strain and a rec-one mutant of Haemophilus influenzae. Journal of Bacteriology 145, $1189-1195$

Page, W. J. \& von Tigerstrom, M. (1979). Optimal conditions for transformation of Azotobacter vinelandii. Journal of Bacteriology 139, 1058-1061.

Palmen, R., Vosman, B., KoK, R., van der Zee, J. R. \& Hellingwerf, K. J. (1992). Characterization of transformation deficient mutants of Acinetobacter calcoaceticus. Molecular Microbiology 6, 1747-1754.

PiechowsKa, M. \& Fox, M. S. (1971). Fate of transforming deoxyribonucleate in Bacillus subtilis. Journal of Bacteriology 108, 680-689.

RudolPh, C. F., Schmid, B. J. \& SAUnders, C. W. (1986). Transformation of Bacillus subtilis by single-stranded plasmid DNA. Journal of Bacteriology 165, 1015-1018.

SAWULA, R. V. \& CRAWFORD, I. P. (1972). Mapping of the tryptophan genes of Acinetobacter calcoaceticus by transformation. Journal of Bacteriology 112, 797-805.

SETo, H. \& Tomasz, A. (1976). Calcium-requiring step in the uptake of deoxyribonucleic acid molecules through the surface of competent pneumococci. Journal of Bacteriology 126, 1113-1118.

SMith, H., Wiersma K., VENEMA G. \& BRON, S. (1985). Transformation in Bacillus subtilis: further characterization of a 75,000-Dalton protein complex involved in binding and entry of donor DNA. Journal of Bacteriology 164, 201-206.

StaCHEL, S. E., Timmerman, B. \& ZAMBR YSKI, P. (1986). Generation of single-stranded T-DNA molecules during the initial stages of TDNA transfer from Agrobacterium tumefaciens to plant cells. Nature, London 322, 706-712.

StewarT, G. J. \& Carlson C. A. (1986). The biology of natural transformation. Annual Review of Microbiology 40, 211-235.

de Vos, W., Venema, G., Canosi, U. \& Trautner, T. A. (1981). Plasmid transformation in Bacillus subtilis: fate of plasmid DNA. Molecular and General Genetics 181, 424-433.

Vosman, B. \& Hellingwerf, K. J. (1991). Molecular cloning and functional characterization of the recA analog from Pseudomonas stutzeri and construction of a $P$. stutzeri recA mutant. Antonie van Leeuwenhoek 59, 115-123.

Vosman, B., Kooistra, J., OliJve, J. \& Venema, G. (1987). Cloning in Escherichia coli of the gene specifying the DNA-entry nuclease of Bacillus subtilis. Gene 52, 175-183. 